\title{
Coal Mines Workers and Motivation
}

\author{
Sanjiv K. Nimbalkar \\ SRM College of Social Work, Gondwana University Gadchiroli, Padoli, India
}

\begin{abstract}
Job satisfaction and commitment as indicators of motivation being a qualitative variable was measured. Analysis of the Likert type attitude scale of job satisfaction and commitment reflects that the workers feel alienated while performing their task. Further they have no authority to exercise power so they feel power-lessness. Because of this they cannot influence other people in relation to their performance and accordingly feel meaningless to work for the organization. The workers feel formlessness to perform their job. There is deviation between the workers objectives and management objective. In the present study, it was found that younger worker area less work motivated than older workers, as per education is concerned more educated worker have low level of motivation than less educated workers. Present organization has monetary incentives and motivation plans but it was found that all the monetary variables tested under present study has shown that it has hardly any role in increasing the level of motivation. Non financial factors as welfare facilities, interpersonal relations and maintenance factors like working condition, safety and security did not show any impact on motivation of workers. Small informal groups formed in formal organization have their own norms and values which differ from the values of large organizations and become obstacle in accepting higher authorities in their small groups. These all various reasons are responsible for the low level of motivation of workers. Hence the workers have low level of motivation.
\end{abstract}

Keywords: workers, motivation, job satisfaction, commitment, powerlessness, meaninglessness, deviance

\section{Introduction}

A girl wants to be a doctor. A man strives for political power. A person in great pain longs for relief. Another person is ravenously hungry and thinks of nothing but food. A boy is lonely and wishes he had a friend. A man had just committed murder, and the police say the motive was revenge. A woman works hard at a job to achieve a feeling of success and competence. These are just a few of the motives that play so large a part in human behavior. They run the gamut from basic wants, such as hunger and sex, to complicated, long term motives, such as political ambition, a desire to serve humanity, or a need to master the environment.

These examples show us that behavior is driven and pulled toward goals. They also show us that such goal-seeking behavior tends to persist. We need a term to refer to the driving and pulling forces which result in persistent behavior directed toward particular goals. The term is motivation.

All human behavior is designed to achieve certain goals and objectives. A motive is a state of individual which motivates him or disposes him for certain action and behavior for seeking a particular goal or goals. It is that inner condition of the organism which initiates or directs behavior toward some goal. Most of the definitions emphases that a motive is an inner state that energizes or channels behavior toward goals. The original Latin word "Movers", i.e., to move, explains that, a motive is restlessness, a lack, a yen, a force, once

Sanjiv K. Nimbalkar, Ph.D., Associate professor, SRM College of Social Work, Gondwana University Gadchiroli. 
in a grip of motive the organism does something, most generally does something to reduce restlessness, to remedy the lack, to alleviate the yen and to mitigate the force. This shows that motivation is an internal force that motivates people to perform certain action or actions directed towards some or other goal.

Motivation has been variously defined by scholars. Moreover following words are included in the definition of motivation such as "desires", "wants", "wishes", "aims", "goals", "needs", motives and incentives. All these terms basically express that all are responsible to activate human being to do something. Motivation represents an unsatisfied need which creates a state of tension or disequilibrium, causing the individual to move in a goal-directed pattern towards restoring a state of equilibrium by satisfying the need.

The above discussion initiated by the psychologists makes us to arrive to the point that "Motive is a quality or condition (instinctual or germinated) of human being in the form of want, desire, wish, need or drive, may be creation of external environment or creation of organism itself'. Motivation can be considered as that internal force, generated by internal organisms need, drives or by some external condition, situation. Both these forces activate people to perform certain action or actions which are goal oriented. So in short, motivation is a force for goal oriented action.

To understand and influence human behavior to perform certain action which is goal oriented, it is necessary to have knowledge of the needs of man. According to Norman Marie, a need may be defined as "a condition requiring the supply of relief", "the lack of anything requisite, desired or useful". In the opinion of Kolasa, "A need is a lack or deficit of something within the system or organism". From the above definition, we may say that a need is a personal, unfulfilled vacancy that determines and organizes all mental process and all behavior in the direction of its attainment.

Needs create tensions-mental strain. Physiological stretching, cultural stress, chemical change and social disequilibrium, and these tensions cannot be released till some wants are satisfied. It is these unsatisfied wants that motivates the individual behavior to satisfy needs and thereby reduce tension. When the individual is unable to satisfy needs, frustration is the result. Some people will then react in a positive manner (constructive behavior), and others in a negative manner (defensive behavior). Needs are interpreted in terms of positive and negative incentives and one's perception of environment in order to produce a certain action or response. Needs, drives, urges, sentiments, expectations, emotions, wants or motives are often used interchangeably. Needs, drives, tensions, expectation and values, acting interdependently, bring about changes in human behavior? It is therefore, necessary to understand needs, every individual who works with others should indentify his own personal needs and expectations of those with whom he works (Clifford et al., 1999).

\section{Work-Motivation Approaches}

The content theories go as far back as the turn of the century, when pioneering scientific managers such as Frederick W. Taylor, Frank Gilbert, and Henry L. Gantt proposed sophisticated wage incentive models to motivate workers. Next came the human relations movement, and then the content theories of Maslow, Herzberg and Alderfer. Following the content movement were the process theories, based mainly on the cognitive concept of expectancy, the process theories are most closing associated with the work of Victor Vroom and Lyman Porter and Ed Lawler.

More recently, equity and, especially, attribution theories have received the most attention in work-motivation.

Figure 1 shows that at present there is a lack of integration or synthesis of the various theories. In addition to the need for integration, a comprehensive assessment of the status of work-motivation theory also noted the 
need for contingency models and group/social process. At present the group of content and process theories have become established explanations for work motivation and there is continued research interest in equity and attribution theories, but no agreed upon overall theory exists (Fred, 1995).

\section{Work Motivation}

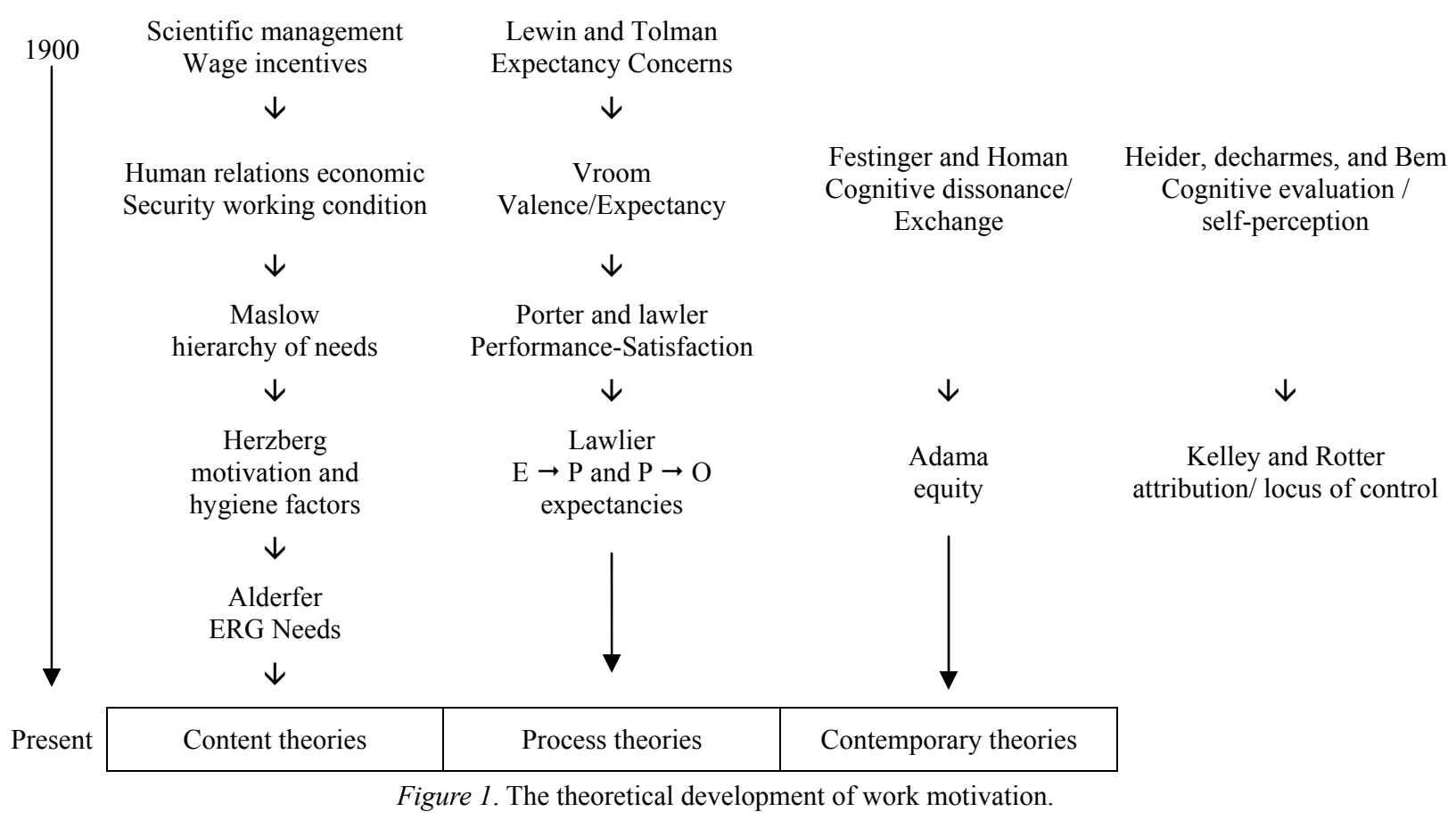

When we speak about organizational goals, the process of motivation is unavoidable as far as man in the organization is concerned. The employer is basically oriented toward the attainment of organizational goals, and employee is more concerned with his personal goals. Both employer and employee in one or the other way are motivated toward their goals. The modern organizations are always, as seen today have different plans, incentives schemes to motivate workers, so that expected goals can be attained. The present study was basically concerned with the causes of higher or lower motivation among the workers working in Western Coalfields Limited, Chandrapur Area, Maharashtra. The present study was just focused to analyze in detail the important role of motivational aspects on the part of organization as well as the worker. The researcher has taken some of the factors which thought to be, affecting the level of motivation of the workers under study. There may be number of other factors which may be affecting motivation but within the frame of the scope of this study few factors were analyzed.

\section{Major Objectives of the Study}

Following were the major objectives of the present study.

(1) To search out the level of motivation among the workers (High, Low);

(2) To find out the hierarchy of motives among the workers with special reference to Indian conditions;

(3) To analyze how the set of hierarchy changes according to the level of motivation;

(4) To probe into the role of financial and non-financial motivators of organization in deciding high and low level of motivation; and

(5) To study the role of informal groups of workers in the process of motivation. 


\section{Hypothesis}

The hypothesis put for the test were as given below:

(1) The level of motivation of workers (High-Low) is closely related with the fulfillment of their expectations from their job;

(2) The set of hierarchy of motives of worker changes according to the personal and family background;

(3) Workers are highly motivated for their work, if there is similarity between goals, set by management and by their own;

(4) Workers are less motivated if a goal set by organization is perceived almost or virtually uncertain to achieve;

(5) The workers are highly motivated with positive motivators and less motivated by negative motivators; and

(6) Informal groups within the industry are more motivated by their informal norms rather than industrial motivators. Financial motivators of industry do not always lead to high motivation.

\section{Area of Study, Sampling Design}

The study was confined to Chandrapur Area of Western Coalfields Limited of Coal India Limited, Chandrapur (M.S.). As stated in the methodology, the study was limited to workers working in production units of 11 mines of Chandrapur area named Hindusthan Lalpeth-1, Hindusthan Lalpeth-3, Manna Inclined, Nandgaon Inclined, Chanda Rayatwari Colliery, Durgapur Rayatwari Colliery, Mahakali Colliery, Hindustan Lalpeth Open Cast, Duragapur Open Cast, Padmapur Open Cast and Bhatadi Open Cast. The universe was consisting of in all 7,064 workers of A, B, C, D, and E category in excavation and 6, 5, 4, 3, 2, and 1 in inclined. These workers are categorized as highly skilled, semi skilled and unskilled workers by WCL organization, who actually works in production units. A sample of 250 workers was selected with the help of sequential list technique $\mathrm{N} / \mathrm{n}=$ (i). So it is "a systematic sample" which is a part of probability sampling method.

\section{Method and Tools of Data Collection}

Both the primary and secondary methods of data collection were adopted for this study.

\section{Primary Method}

Assuming the possibility that workers at production department may be either literate or illiterate, an interview method was used for collection of data. A structured interview schedule comprising of primarily closed questions were included. Scaling technique was administered for the same for measuring the level of motivation. The interviews were further supported by observation method so that exact condition of the work place, the various facilities provided to the workers and the interpersonal relations can be minutely observed, as they play an important role in workers motivation.

\section{Secondary Method}

Some of the data necessary for study was collected through secondary method such as the development and history of organization various schemes adopted for providing incentives to motivate the workers, the official records and documentary sources was considered for this purpose.

\section{Research Design}

The present study was descriptive and diagnostic, as far as research design is concerned. 
It was descriptive in nature because an attempt was made to describe accurately the characteristics of workers included in the sample. Secondly there was micro description of wants, needs, desires, aims, drives of the workers fitted in the hierarchy of needs and also the incentives, motivators which activate their motives.

It was diagnostic study because it was concerned with discovering and testing the association of some major variables such as degree of motivation and hierarchy of needs, association of financial and non-financial incentives to decide the higher and lower motivation, relation of values and norms in informal group with the motivation of the workers.

The study was partly descriptive and partly diagnostic (not exploratory) because the research question were completely based upon the existing knowledge of the problem to be investigated.

\section{Measurement of Motivation}

The researcher had mentioned in the objectives and hypothesis of the present research which was very much necessary to find out the level of motivation of coal mines workers who were taken as a sample under present study. Further it was also hypothesized whether this level of motivation may be outcome of different factors which are named as factors, factors within the organization and factors out of the organization. The researcher had also this curiosity whether the level of motivation and workers hierarchy of needs are interrelated or not.

For the measurement of motivation, the researcher had used to powerful indicators such as job satisfaction and commitment of the workers, with this assumption that the level of motivation (high or low) results to high job satisfaction and high commitment, similarly low level of motivation is the result of low job satisfaction and low commitment.

The indicators of job satisfaction where general statements opted from "A Handbook of research design and Social Measurement", in which total 18 statements were given, to the respondents on five point "Likert" type scale ranging from fully agree to fully disagree. The commitment scale was opted from the same along with "The cane model of work motivation" (University of Southern California, 1999). This scale includes indicators like powerlessness, meaning-lessens, norm-lessens, deviance and conformity. Five options were given to respondents ranging from strongly agree to strongly disagree for the responses.

"Job satisfaction" and "Commitment", the two important attitudes as a powerful indicators of motivation were assembled together for the measurement of motivation, and to find out the range between the lowest and the highest score gained.

A person can have thousands of attitudes, but organizational behavior focuses attention on a very limited number of job related attitudes. "An attitude is a dispositional readiness to respond to certain situations, persons or objects in a consistent manner which has been learned and has become ones typical mode of response" (Frank, 1962), "Attitude can be defined as lasting, general evaluation of people (including oneself), objects or issues" (Breckler, as cited in Robert et al., 1988). Most social psychologists accept the ABC model of attitudes which suggests that an attitude has three components: affect, behavior and cognition (e.g., Breckler, as cited in Robert et al., 1988). "The affect component refers to positive or negative emotions-our gut-level feelings about something, the behavior component involves our intentions to act in certain ways, to engage in behaviors that are somehow relevant to our attitudes; the cognition component refers to the thinking and interpreting that goes into forming or using an attitude" (Breckler, as cited in Robert et al., 1988). Each attitude, then is made up of a cluster of feelings, likes and dislikes, behavioral intention, thoughts, and ideas. 
The degree or strength of a person's attitudes may vary from extremely positive through a gradation to extremely negative. These job related attitudes, job satisfaction and commitment, tap positive or negative evaluations that employer hold about aspects of their work environment. In the present study, there are two important attitudes, job-satisfaction and commitment which are most powerful and important indicators of motivation.

The scientific study of attitudes requires that they be measured. This means that peoples evaluation of a given attitude object must be translated into some number system. Many techniques are in current use. They vary from very simple very complex. The simplest techniques permit us to place concepts, things, or people into a "favorable" or "unfavorable" category.

As stated earlier in the objectives, major focus of this study is to study the level of motivation of workers towards their work and to find out causes for higher and lower level of work-motivation among them. In any scientific social research, there are always difficulties to measure social phenomenon. Social research involves measurement of things, their properties and their responses to a certain stimuli, and the quality of research depends upon the fruitfulness of measurement procedure administered. Even though it is difficult to measure attributes, there are certain devices through which this measurement is possible. It is obvious that the success of measurement instruments depends upon the reliability, validity and precision of the scale. There are scales which are meant for attribute measurement through which the position of the individual can be located on the given scale.

Referring to the objectives of the present study, it was felt accessory to measure the motivation of the workers. "Motivation can be considered as that internal force, generated by internal organisms needs, drives or by some external condition, situation. Both these forces activates people to perform certain actions or action which are goal oriented". To measure such a state of mind, a "summated scale" was used for this purpose, which is Likert type scale.

Job-satisfaction and commitment, two major indicators of motivation can be measured or determined through the indicators such as state of Alienation, consisting of powerlessness, meaninglessness and formlessness, secondly state of deviance and lastly the state of conformity. Because of this socio-psychological condition's of his emotion, "Alienation denotes a socio-psychological condition of the individual which involves his estrangement from certain aspects of his social existence".

Alienation is a state of socio-psychological estrangement of an employee from the organization resulting in loss of interest on work creating low motivation. Hence the employee is unable to share the goals and aspiration of the organization. "Powerlessness is a condition of isolation in which a person cannot influence his social situation".

Winter (1973, p. 5) has defined social power is "the ability or capacity of a person to produce (consciously or unconsciously) intended effects on the behavior or emotions of another person". The goals of the power motivation are to influence, control, persuade, lead, charm others, and to enhance one own reputation in the eyes of other people. People with strong power motivation desire satisfaction from achieving these goals. When they are unable to achieve these goals a negative state of mood or mind generates which results in low motivation.

Powerlessness is a feeling of an employee in which he finds himself unable to influence the work situation, he is distracted and not motivated to perform in the particular work situation as he is unable to achieve the goal of power motivation. 
"Meaninglessness is a feeling on the part of the individual that he has no guides for conduct or belief".

An implicit implication in this research is that commitment and active pursuit of a work goal is always accompanied by mental effort. Meaninglessness is a feeling on the part of an employee that his ideas and actions are of no use for the organization and whether he performs or not, is immaterial to the organization. This feeling results into negative motivation.

"Formlessness is the individuals feeling that illegitimate means are required to achieve goals".

It is presumed that if we perceive a task as very difficult, that perception reflects an analysis of our own task-relevant skills. Formlessness is a mental state situation in which the employees finds that there are not set norms with reference to which he can determine behavior or action in the organization. There is nothing to distinguish between legitimate and illegitimate in a work situation. This develops an attitude of indifference resulting in loss of motivation.

"Deviance refers to motivated tendency for action to contravene a norm".

Commitment as well as motivation is influenced by values, emotion and personal agency. Effort is primarily influenced by specific and detailed self efficacy assessments of the knowledge required to achieve tasks. When a person's values, emotion and personal agency are not satisfied he starts deviating from the desired goals. Deviance is a tendency for deliberately turning aside or away from the set norms of conduct in which the employee displays negative motivation.

"Conformity is acting in accordance with norms known to individual" (R. K. Merton).

Once a person is committed to a goal, he must make a plan to achieve the goal. A key element of all goal-directed planning is our personal assessment of the necessary skills and knowledge required to achieve a goal. The more familiar the goal and the more knowledge and skill we believe we have gained in the pursuit of similar goals, the less effort we are inclined to invest. Such situations creates a positive mood which conforms an employee in work situation. Thus, conformity is a mental condition in which an employee attempts to be in agreement with, comply with generally accepted rules and norms of conduct. This is the mental situation in which an employee feels highly satisfied which results in high motivation.

The above mentioned as state of alienation consisting of powerlessness, meaninglessness and formlessness and deviance are the mental condition which results in negative mood. This negative mood states inhibit commitment and are barriers to goal commitment. Such mental condition distracts an employee in achieving the goal resulting in low motivation. Conformity is a positive mood. Positive moods may be characterized by happiness, joy, contentment and optimism. This positive emotion foster commitment, which results in high motivation.

\section{Methods of Scaling}

An attitude scale attempts to obtain a precise measure of the extremity of people's attitude. The accuracy of the measurement can be increased by using many items that are all related to the same issue. Attitude scales use such items. The items on an attitude scale, inquire about things that are known to be related to the attitude topic. People who are favorable toward something usually have a belief structure that is different from people who hold an unfavorable attitude.

Tests of attitude are based upon several assumptions:

(1) The scale should deal with controversial questions;

(2) An individual's feelings and insights in regard to the question will determine his responses to the various statements that are made; and 
(3) The statements can be scaled regarding the degree to which they favor, or are opposed to, the question under consideration.

Keeping the above assumptions in mind a summated scale was constructed, and assembled. This scale consists of a large number of positive and negative statements considered relevant to the above indicators. For this purpose, a "Likert scale" was administered (Rensis, as cited in Rajendra et al., n.d.).

Likert suggested the use of an attitude scoring technique and is regarded by many as at least as reliable. Each item, or statement, in the attitude scale is followed by five responses, one of which is checked by the subject. The responses, indicating degree of strengths of attitude are: "Strongly agree" (SA), "Somewhat agree" (SWA), "Undecided" (UD), "Disagree" (DA), and "Strongly disagree" (SDA), which is a 5-point scale. So also the values are assigned according to positive and negative statements. Arbitrary scoring weights of 5, 4, 3, 2, 1 were assigned for the positive statements, where as 1, 2, 3, 4, 5 were assigned for the negative statements. An individual's score on a particular attitude scale is the sum of his ratings on all items.

The statements were administered to a small sample of subject representative of workers under (P. Testing). Finally the responses were analyzed with the help of total score, to determine which of the statements discriminate most clearly between the high score and lowest scores. The items with low discriminatory power or those that do not show a substantial co-relation with the total score were eliminated to ensure that the interview schedule is internally consistent, i.e., each statement is related to some general attitude.

After calculating the responses, the following tables are prepared to show the frequency first and secondly the level of motivation as calculated through the total score.

From the analysis of Table 1, it can be inferred that, the workers in the organization are interested but the environment in which they work is not proper and hence the respondents perceive their job to be monotonous and therefore they are dissatisfied with their job.

Table 1

Measurement of Level of Motivation

\begin{tabular}{llllllll}
\hline Sr. No. & Statements & SA & SWA & UD & DA & SDA & Total \\
\hline 1 & $\begin{array}{l}\text { There can be improvement is some } \\
\text { of my working in my environment. }\end{array}$ & $08(3.20)^{*}$ & $06(2.40)$ & $14(5.60)$ & $161(64.40)$ & $61(24.40)$ & $250(100)$ \\
2 & $\begin{array}{l}\text { My work is hobby for me. } \\
3\end{array}$ & $02(0.80)$ & $33(13.20)$ & $28(11.20)$ & $124(49.60)$ & $63(25.20)$ & $250(100)$ \\
& $\begin{array}{l}\text { My job is interesting to keep me } \\
\text { away from monotony. }\end{array}$ & $08(3.20)$ & $01(0.40)$ & $34(13.60)$ & $147(58.80)$ & $60(24.00)$ & $250(100)$ \\
4 & $\begin{array}{l}\text { In my opinion my friends on job } \\
\text { take more interest in their work. }\end{array}$ & $35(14.00)$ & $115(46.00)$ & $78(31.20)$ & $21(8.40)$ & $1(0.40)$ & $250(100)$ \\
5 & $\begin{array}{l}\text { My work is not healthier in my } \\
\text { opinion. }\end{array}$ & $29(11.60)$ & $116(46.40)$ & $56(22.40)$ & $35(14.00)$ & $14(5.60)$ & $250(100)$ \\
6 & $\begin{array}{l}\text { I am more interested in work than } \\
\text { spending it unnecessary. }\end{array}$ & $06(2.40)$ & $04(1.60)$ & $33(13.20)$ & $135(54.00)$ & $72(28.80)$ & $250(100)$ \\
7 & $\begin{array}{l}\text { Most of the times it feel monotonous } \\
\text { on my jobs. }\end{array}$ & $42(16.80)$ & $91(36.40)$ & $58(23.20)$ & $52(20.80)$ & $07(2.80)$ & $250(100)$ \\
8 & $\begin{array}{l}\text { I am fully satisfied by my job. } \\
\text { Many times I have to compel myself }\end{array}$ & $02(0.80)$ & $13(5.20)$ & $18(7.20)$ & $158(63.20)$ & $59(23.60)$ & $250(100)$ \\
9 & $\begin{array}{l}\text { to go to job. } \\
\text { In my opinion I am satisfied on my }\end{array}$ & $24(9.60)$ & $124(49.60)$ & $31(12.40)$ & $42(16.80)$ & $29(11.60)$ & $250(100)$ \\
10 & $\begin{array}{l}\text { job temporarily. } \\
\text { I do not feel that my current work is } \\
\text { more interesting than other job } \\
\text { which I could get. }\end{array}$ & $39(15.60)$ & $102(40.80)$ & $73(29.20)$ & $30(12.00)$ & $6(2.40)$ & $250(100)$ \\
\hline 11 & & & $61(24.40)$ & $28(11.20)$ & $07(2.80)$ & $250(100)$ \\
\hline
\end{tabular}


Table 1 to be Continued

\begin{tabular}{|c|c|c|c|c|c|c|c|}
\hline 12 & $\begin{array}{l}\text { Definitely my work is not interesting } \\
\text { for me. }\end{array}$ & $82(32.80)$ & $105(42.00)$ & $27(10.80)$ & $28(11.20)$ & $08(3.20)$ & $250(100)$ \\
\hline 13 & $\begin{array}{l}\text { In my opinion I am definitely happy } \\
\text { by my work compared to other. }\end{array}$ & $03(1.20)$ & $04(1.60)$ & $30(12.00)$ & $128(51.20)$ & $85(34.00)$ & $250(100)$ \\
\hline 14 & $\begin{array}{l}\text { Most of the day I am enthusiastic on } \\
\text { my work. }\end{array}$ & $01(0.40)$ & $02(0.80)$ & $37(14.80)$ & $119(47.60)$ & $91(36.40)$ & $250(100)$ \\
\hline 15 & $\begin{array}{l}\text { I feel every day of my job will never } \\
\text { end. }\end{array}$ & $42(16.80)$ & $69(27.60)$ & $66(26.40)$ & $57(22.80)$ & $16(6.40)$ & $250(100)$ \\
\hline 16 & $\begin{array}{l}\text { I like my work more compared to } \\
\text { other workers. }\end{array}$ & $01(0.40)$ & $03(1.20)$ & $19(7.60)$ & $170(68.00)$ & $57(22.80)$ & $250(100)$ \\
\hline 17 & My work is not interesting at all. & $47(18.80)$ & $84(33.60)$ & $60(24.00)$ & $43(17.20)$ & $16(6.40)$ & $250(100)$ \\
\hline 18 & $\begin{array}{l}\text { I am unhappy because of acceptance } \\
\text { of this job. }\end{array}$ & $13(5.20)$ & $75(30.00)$ & $31(12.40)$ & $49(19.60)$ & $82(32.80)$ & $250(100)$ \\
\hline 19 & Full authority to take decision. & $15(6.000$ & $47(18.80)$ & $17(6.80)$ & $107(42.80)$ & $64(25.60)$ & $250(100)$ \\
\hline 20 & Can influence people. & $03(1.20)$ & $11(4.40)$ & $44(17.60)$ & $147(58.80)$ & $45(18.00)$ & $250(100)$ \\
\hline 21 & No power to decide my role. & $25(10.00)$ & $111(44.40)$ & $65(26.000$ & $42(16.80)$ & $07(2.80)$ & $250(100)$ \\
\hline 22 & Working without any guidance. & $33(13.20)$ & $83(33.200$ & $60(24.00)$ & $63(25.20)$ & $11(4.40)$ & $250(100)$ \\
\hline 23 & Lost my faith in the values. & $26(10.40)$ & $76(30.40)$ & $52(20.80)$ & $57(22.80)$ & $39(15.60)$ & $250(100)$ \\
\hline 24 & Meaning-less to instructions. & $42(17.20)$ & $92(36.80)$ & $41(16.40)$ & $57(22.80)$ & $17(6.80)$ & $250(100)$ \\
\hline 25 & $\begin{array}{l}\text { Give importance to goals of } \\
\text { organization. }\end{array}$ & - & $12(4.80)$ & $29(11.60)$ & $145(58.00)$ & $64(25.60)$ & $250(100)$ \\
\hline 26 & $\begin{array}{l}\text { Should not bother about prescribed } \\
\text { ways to achieve organizational goals. }\end{array}$ & $42(17.20)$ & $104(41.60)$ & $23(9.20)$ & $58(23.20)$ & $22(8.80)$ & $250(100)$ \\
\hline 27 & $\begin{array}{l}\text { Makes no difference to always keep } \\
\text { in mind organizational goals. }\end{array}$ & $65(26.000$ & $122(48.80)$ & $15(6.00)$ & $30(12.00)$ & $18(7.20)$ & $250(100)$ \\
\hline 28 & Conscious about the values and norms. & $05(2.00)$ & $26(10.40)$ & $54(21.60)$ & $127(50.80)$ & $38(15.20)$ & $250(100)$ \\
\hline 29 & Play role beyond the regulation. & $16(6.40)$ & $42(16.80)$ & $49(19.60)$ & $108(43.20)$ & $35(14.00)$ & $250(100)$ \\
\hline 30 & Performing role beyond expectation. & $09(3.60)$ & $32(12.80)$ & $51(20.40)$ & $104(41.60)$ & $54(21.60)$ & $250(100)$ \\
\hline 31 & $\begin{array}{l}\text { Benefit of organization to work } \\
\text { according to predecided objectives. }\end{array}$ & $90(36.00)$ & $139(55.60)$ & $15(6.00)$ & $05(2.00)$ & $01(0.40)$ & $250(100)$ \\
\hline 32 & Playing role according to requirement. & $75(30.00)$ & $144(57.60)$ & $23(9.20)$ & $07(2.80)$ & $01(0.40)$ & $250(100)$ \\
\hline 33 & Organizational values are clear. & $01(0.40)$ & $05(2.00)$ & $32(12.80)$ & $130(52.00)$ & $82(32.80)^{*}$ & $250(100)$ \\
\hline
\end{tabular}

Note. ${ }^{*}$ Figures in the parentheses represent percentage of total.

The respondents cannot take simple decision in relation to their job and hence they feel alienated while performing their task. Further they have no authority to exercise power so they feel power-less. Because of this they cannot influence other people in relation to their performance and accordingly feel meaningless to work for the organization. As far as the values of the job is concerned, the overall faith on the part of the respondents are at lower level and feel norm less to perform their job. There is a deviation between the workers objective and managements objective. The respondents would like to work at average level irrespective of their ability. Since there exist the deviation between the workers objective and managements objective, the workers in the organization are not committed to achieve the organizational goals. Most of the workers are not fully aware of the norms of the organization and the mental condition on the part of the workers are not perceive to be positive to achieve the organizational goals. Since the workers feel less conferred to perform their job.

\section{Level of Motivation}

For measuring the level of motivation of workers, 5 point scale was prepared. As stated earlier a motivation scale consisting of indicators as job-satisfaction and commitment has been prepared and 
standardized upon the model of Likert scaling technique. To make the whole analysis more meaningful and fruitful, it was thought to take out the position of each worker on the motivation scale, on the basis of their acquired score. All the 33 statements were given score value, the positive statement were calculated from 5 to 1 and negative statement from 1 to 5 .

After calculating the score, it was found that the score were ranging between 63 to 114 . The score was divided into two groups, i.e., high motivation and low motivation. The frequency of the workers attitude score to the statements was 63 to 88 , low level of motivation and 89 to 114 , higher level of motivation.

Table 2 gives a clear division of the worker as per their level of motivation.

Table 2

Workers and Level of Motivation

\begin{tabular}{lllcc}
\hline Sr. No. & Level of motivation & Score & Frequency & Percentage $(\%)$ \\
\hline 1 & Low & $63-88$ & 190 & 76.00 \\
2 & High & $89-114$ & 60 & 24.00 \\
& Total & & 250 & 100.00 \\
\hline
\end{tabular}

The reflection from Table 2 indicates the level of motivation of the workers. It indicates that out of 250 respondents, majority 190 , i.e., $76.00 \%$ respondents score range between 63 to 88 showing low level of work motivation. While 60 respondents, i.e., $24.00 \%$ respondents score range between 89 to 114 showing high level of work-motivation.

The analysis of the above table reveals that majority of the workers in Western Coalfields Limited, Chandrapur Area have low level of motivation, i.e., they have low level of job-satisfaction and low level of commitment.

\section{Hierarchy of Needs}

The behavior of individuals at a particular moment is usually determined by their strongest need. An interesting framework that explain the strength of certain need was developed by Abraham Maslow (as cited in Paul et al., 1988). According to Maslow there seems to be a hierarchy into which human needs arrange themselves.

Figure 2 shows how the needs are arranged in hierarchy.

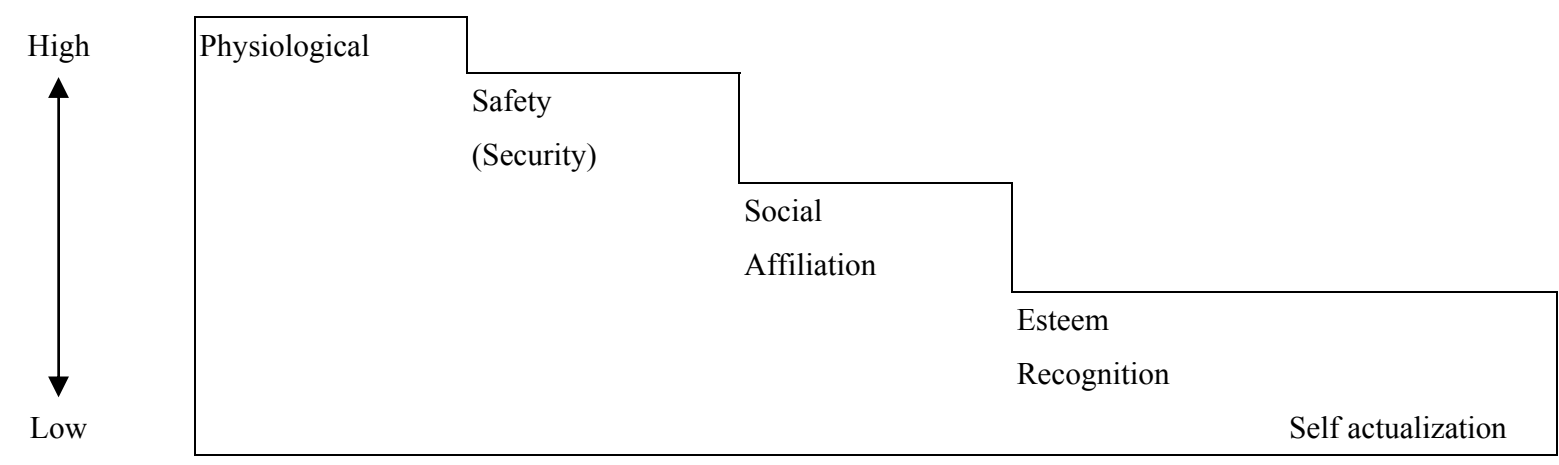

Figure 2. Maslow's hierarchy of needs.

The physiological needs are shown at the top of the hierarchy because they tend to have the highest strength until they are somewhat satisfied. These are the basic human needs to sustain life itself-food, clothing, 
shelter. Until these basic needs are satisfied to the degree needed for the sufficient operation of the body, the majority of a person's activity will probably be at this level, and the other needs will provide little motivation.

Once physiological needs become gratified, the safety, or security, needs become predominant. Once physiological and safety needs are fairly well satisfied, social, or affiliation need will emerge as dominant in the need structure. After individuals begin to satisfy their need to belong, they generally want to be more than just a member of their group. They then feel the need for esteem both; self-esteem and recognition from other. Satisfaction of the esteem needs produces feelings of self confidence, prestige, power and control. People begin to feel that they are useful and have some effect on their environment.

Once Esteem needs begin to adequately satisfied, the self-actualization needs become more proponents. Self actualization is the need to maximize ones potential, whatever it may be. As Maslow expressed it, "What a man can be he must be". Thus self-actualization is the desire to become what one is capable of becoming. Individuals satisfy this need in different ways.

As stated in the objectives of the present study, researcher was curious to find out the hierarchy of motives among the workers with special reference to Indian condition and to analyses how the set of hierarchy changes. The researcher arranged the needs in a order and asked the workers to give preference 1, 2, 3, 4, and 5 as per their choice as the workers think they want to be satisfied. Table 3 shows the respondents preferences to the needs. Further the preferences were given scores of 5, 4, 3, 2, and 1. I preference was multiplied by 5, II preference was multiplied by 4, III preference was multiplied by 3, IV preference was multiplied by 2 and V preference was multiplied by 1 , and the total score was obtained by adding them to know which needs are dominating in the need structure according to the preferences.

Table 3

Preferences to the Needs

\begin{tabular}{|c|c|c|c|c|c|c|}
\hline \multicolumn{7}{|l|}{ Needs } \\
\hline Sr. No. & Preferences & Physiological & $\begin{array}{l}\text { Safety \& social } \\
\text { security }\end{array}$ & Social recognition & Esteem & $\begin{array}{l}\text { Self actualization } \\
\text { at work place }\end{array}$ \\
\hline 1 & $\mathrm{I}$ & $12 \times 5=60$ & $93 \times 5=465$ & $23 \times 5=114$ & $28 \times 5=140$ & $94 \times 5=470$ \\
\hline 2 & II & $13 \times 4=52$ & $79 \times 4=316$ & $33 \times 4=132$ & $38 \times 4=152$ & $87 \times 4=348$ \\
\hline 3 & III & $31 \times 3=93$ & $33 \times 3=99$ & $79 \times 3=237$ & $83 \times 3=249$ & $24 \times 3=72$ \\
\hline 4 & IV & $17 \times 2=34$ & $21 \times 2=42$ & $101 \times 2=202$ & $81 \times 2=162$ & $30 \times 2=60$ \\
\hline 5 & $\mathrm{~V}$ & $177 \times 1=177$ & $24 \times 1=24$ & $14 \times 1=14$ & $20 \times 1=20$ & $15 \times 1=15$ \\
\hline \multicolumn{2}{|c|}{ Total respondents/score } & $250 / 356$ & $250 / 946$ & $250 / 700$ & $250 / 723$ & $250 / 965$ \\
\hline \multicolumn{2}{|c|}{ Hierarchy of needs } & $\mathrm{V}$ & II & IV & III & I \\
\hline
\end{tabular}

Table 3 reflecting on the preferences to the needs which the respondents think should be fulfilled clearly shows that the majority of the respondents has given I preference to self actualization at work place, and this need has gained the score of 965 and is placed on I preference. Needs of safety and social security has gained a score of 946, and is placed on II preference. Esteem need has gained a score of 723 and is place on III preference. Whereas need of social recognition has gained a score of 700 and is placed on IV preference, while physiological need has gained lowest score of 356 and is placed on $\mathrm{V}$ preference.

The highlights of Table 3 reveal that the workers are of the opinion that their need of self actualization is not satisfied in the organization so this need should be satisfied firstly. Secondly need of safety and social security should be satisfied. Thirdly esteem need should be satisfied. Fourthly social recognition need should be 
satisfied and lastly physiological need should be satisfied. The analysis of the table clearly shows that the workers physiological and social recognition needs are satisfied fairly in the organization, so the workers have placed this need at V and IV place respectively. Whereas the workers have given I and II preference to self actualization at work place and safety, social security need respectively. This shows that self actualization at work place and safety, social security needs are not satisfied in the organization. Hence the workers have low level of work-motivation.

Table 4

Age \& Level of Motivation

\begin{tabular}{lllcr}
\hline Sr. No. & Workers age (in years) & \multicolumn{2}{c}{ Level of motivation } & Total \\
\hline 1 & & High & Low & $86(100)$ \\
2 & $35-40$ & $06(6.98)$ & $80(73.02)$ & $100(100)$ \\
3 & $41-46$ & $26(26)$ & $74(74)$ & $40(100)$ \\
4 & $47-52$ & $13(32.50)$ & $27(67.50)$ & $24(100)$ \\
& $53-58$ & $15(62.50)$ & $09(37.50)$ & 250 \\
\hline
\end{tabular}

Table 4 shows that majority of the workers 100 belong to age group of 41-46 years among whom $74 \%$ showed low level of motivation, while $26 \%$ shows high level of work motivation. Whereas 24 workers belong to the age group of 53 to 58 among whom $15(62.50 \%)$ have high level of work motivation while $09(37.50 \%)$ have low level of work motivation.

"It is a popular belief that as industrial workers grow older, they tend to be more contended and satisfied with their jobs". It is probable that because younger workers tend to get less satisfied due to very high expectation, less adjustment and other causes, such an inference about level of motivation among older age group of workers appears plausible.

From the analysis of Table 4, it can be inferred that as the age group goes on increasing the level of motivation too goes on increasing. In the same way younger workers tend to show low motivation than older workers.

Table 5

Education \& Level of Motivation

\begin{tabular}{lllcr}
\hline Sr. No. & Education & \multicolumn{2}{c}{ Level of motivation } & Total \\
\hline 1 & & High & Low & \\
2 & Below S.S.C. & $33(61.11)$ & $21(38.89)$ & $54(100)$ \\
3 & S.S.C. & $23(18.86)$ & $99(81.14)$ & $122(100)$ \\
4 & H.S.S.C. & $02(4.54)$ & $42(95.46)$ & $44(100)$ \\
& Graduate & $02(6.67)$ & $28(93.33)$ & $30(100)$ \\
& Total & 60 & 190 & 250 \\
\hline
\end{tabular}

From Table 5, it is evident that 122 respondents' level of education is up to S.S.C. among these, 99 (81.14\%) have low level of work motivation, while $23(18.86 \%)$ have high level of work motivation. 54 respondent have education level below S.S.C., among these $33(61.11 \%)$ respondents have high level of work motivation, while $21(38.89 \%)$ have low level of work-motivation.

Analysis Table 5 indicates that as the level of education goes on increasing the level of motivation decreases. Less educated workers shows to be more motivated than more educated workers. 
Table 6

Category of Job \& Level of Motivation

\begin{tabular}{|c|c|c|c|c|}
\hline Sr. No. & Category of job & & motivation & Total \\
\hline & & High & Low & \\
\hline 1 & Highly skilled & $17(10.83)$ & $140(89.17)$ & $157(100)$ \\
\hline 2 & Semi skilled & $21(30.43)$ & $48(69.57)$ & $69(100)$ \\
\hline \multirow[t]{2}{*}{3} & Unskilled & $22(91.67)$ & $02(8.33)$ & $24(100)$ \\
\hline & Total & 60 & 190 & 250 \\
\hline
\end{tabular}

Table 6 indicates the relationships between designation and level of motivation, inferring that 157 respondents are highly skilled workers. Among the 157 respondents, 140 (89.17\%) have low level of work-motivation, while $17(10.83 \%)$ respondents have high level of work-motivation.

24 respondents are unskilled, out of which 22 (91.67\%) respondents have high level of work-motivation, while $2(8.33 \%)$ respondents have low level of work-motivation.

The analysis of Table 6 shows the trend that as the level of designation improves the level of work-motivation goes on decreasing. The reasons may be that the workers may not be having liberty to use their organizational powers as well as the unfavorable response from the lower level workers within the organization.

Table 7

Length of Service \& Level of Motivation

\begin{tabular}{lllcc}
\hline Sr. No. & Length of service (In years) & \multicolumn{1}{c}{ Level of motivation } & Total \\
\hline 1 & & High & Low & $78(100)$ \\
2 & $10-15$ & $16(20.51)$ & $62(79.49($ & $100(100)$ \\
3 & $16-21$ & $19(19)$ & $81(81)$ & $62(100$ \\
4 & $22-27$ & $19(30.65)$ & $43(69.35$ & $10(100)$ \\
& 28 years \& above & $06(60)$ & $04(40)$ & 250 \\
\hline
\end{tabular}

The data presented in Table 7 shows that the length of service of 100 respondents is between 16 to 21 years. Among thee, $81 \%$ have low level of work-motivation while $19 \%$ have high level of work-motivation. Whereas the length of 10 respondent's is 21 years and above among these $6(60 \%)$ respondent's have high level of work-motivation, while 4 (40\%) respondent's have low level of worm-motivation.

From the analysis of Table 7, it can be inferred that as the length of service increases there is a tendency to be slightly motivated towards work.

Table 8

Monthly Wages \& Level of Motivation

\begin{tabular}{lllcc}
\hline Sr. No. & Monthly wages (in Rs.) & Ligh & Low & Total \\
\hline 1 & & $15(17.86)$ & $69(82.14)$ & $84(100)$ \\
2 & $16,000-18,000$ & $13(14.13)$ & $79(85.87)$ & $92(100)$ \\
3 & $18,001-20,000$ & $17(33.33)$ & $34(66.67)$ & $51(100)$ \\
4 & $20,001-22,000$ & $09(64.28)$ & $05(35.72)$ & $14(100)$ \\
5 & $22,001-24,000$ & $06(66.67)$ & $03(33.33)$ & $09(100)$ \\
& 24,001 and above & 60 & 190 & 250 \\
\hline
\end{tabular}


It is evident from Table 8 that the monthly wages of majority 92 respondents is between Rs. 18,001 to 20,000. Among this 79 (85.87\%) respondents have low level of work-motivation, while 13 (14.13\%) respondents have high level of work-motivation.

From the analysis of Table 8 , it is clear that increasing salary does not have any effect on the increments of motivation. It is due to the unsatisfied need of money and property; any individual can never show his total satisfaction as far as money is concerned.

Table 9

Financial Policies \& Level of Motivation

\begin{tabular}{lllcr}
\hline Sr. No. & Financial policies & High & Low & Total \\
\hline & & $48(64.86)$ & $26(35.14)$ & $74(100)$ \\
2 & Fully satisfied & $10(6.81)$ & $137(93.19)$ & $147(100)$ \\
3 & Party satisfied & $02(6.90)$ & $27(93.10)$ & $29(100)$ \\
& Little satisfied & 60 & 190 & 250 \\
\hline
\end{tabular}

Table 9 concerning about managements policies about financial motives and level of motivation shows that majority 147 respondents are party satisfied by managements policies and among this 137 (93.19\%) have low level of work-motivation and $10(6.81 \%)$ respondents have high level of work-motivation. A substantial number of respondents 74 are fully satisfied by management's financial motivation programmes. Out of this 74 respondents $48(64.86 \%)$ have high level of work-motivation whereas $26(35.14 \%)$ have low level of work-motivation. A small number of respondents 29 are little satisfied about management's financial schemes and out of this 29 respondents $27(93.10 \%)$ respondents have low level of work-motivation and only $2(6.90 \%)$ respondents have high level of work-motivation.

Table 10

Working Conditions \& Level of Motivation

\begin{tabular}{lllcr}
\hline Sr. No. & Working conditions & \multicolumn{2}{c}{ Level of motivation } & Total \\
\hline & & High & Low & \\
2 & Fully satisfied & $51(79.69)$ & $13(20.31)$ & $64(100)$ \\
3 & Somewhat satisfied & $09(7.70)$ & $108(92.30)$ & $177(100)$ \\
3 & Not satisfied & -- & $69(100)$ & $69(100)$ \\
& Total & 60 & 190 & 250 \\
\hline
\end{tabular}

Table 10 highlights the workers' opinion about over all working condition and level of motivation. Out of 250 respondents, majority 117 respondents are of the opinion that the overall working condition in coal mines in somewhat good. Among this, 108 (92.30\%) respondents have low level of work-motivation, while a small proportion 9 (7.70\%) have high level of work-motivation.

The reflections of the analysis of Table 10 clearly shows that the majority of the workers in Western Coalfields Limited, Chandrapur Area, are of the opinion that the overall working condition in Mines is somewhat good and not good so the workers have low level of work-motivation. This reveals that the working condition has a direct impact on the level of work-motivation of the workers as this is the place were workers have to work for 8 hours in a day. 
Table 11

Intramural Welfare Facilities \& Level of Motivation

\begin{tabular}{lllcr}
\hline Sr. No. & Intramural welfare facilities & & Level of motivation & Total \\
\hline & & High & Low & \\
\hline 2 & Fully satisfied & $54(83.07)$ & $11(16.93)$ & $65(100)$ \\
3 & Partly satisfied & $06(5.45)$ & $104(94.55)$ & $110(100)$ \\
& Unsatisfied & -- & $75(100)$ & $75(100)$ \\
& Total & 60 & 190 & 250 \\
\hline
\end{tabular}

The reflections of Table 11 indicate that 110 respondents are partly satisfied with welfare facilities inside the mines. Among this 104 (94.55\%) have low level of work-motivation, while only a small number of respondents 4 (5.45\%) have high level of work-motivation.

The analysis of Table 11 reflects that majority of the workers are partly satisfied and unsatisfied by the welfare facilities inside the mine and have low level of work-motivation. This clearly shows that welfare facility has a direct impact on level of motivation of the workers.

Table 12

Extra-mural Welfare Facilities \& Level of Motivation

\begin{tabular}{lllcr}
\hline Sr. No. & Extra-mural welfare facilities & & Level of motivation & Total \\
\hline 1 & & High & Low & $71(100)$ \\
2 & Fully satisfied & $54(76.05)$ & $17(23.95)$ & $92(100)$ \\
3 & Partly satisfied & $06(6.53)$ & $86(93.47)$ & $87(100)$ \\
& Unsatisfied & -- & $87(100)$ & 250 \\
\hline
\end{tabular}

Concerning level of motivation and welfare facilities outside mines, Table 12 indicates that majority 92 respondents are partly satisfied with welfare facilities provided outside the mines and among this 86 (93.47\%) respondents have low level of work-motivation while a little proportion 06 (6.53\%) respondents have high level of work-motivation.

The analysis of Table 12 highlights that majority of the workers are partly satisfied and not satisfied by the provision of welfare facilities outside the mines. From this, it is clear that welfare facilities outside mines are related with level of motivation of the workers.

The reflection Table 13 concerning about interpersonal relationship with workers under self, co-workers and senior officials reveals that as per workers under self are concerned, 119 respondents are of the opinion that their relationships are moderate and out of this, $100(92.43 \%)$ respondents have low level of work-motivation, while $9(7.57 \%)$ respondents have high level of work-motivation.

Concerning Relationship with co-workers and level of motivation; 146 respondents are of the opinion that their relationships are moderate. Out of this 146 respondents 143 (97.95\%) respondents have low level of work-motivation and only $3(2.05 \%)$ have high level of work-motivation.

Regarding the interpersonal relationship with senior officials and level of motivation, the data presented in table high-light that 117 respondents have a moderate relationship with senior officials. Among this, 111 $(94.88 \%)$ respondents have low level of work-motivation and $6(5.12 \%)$ respondents have high level of work-motivation. 
The reflections of Table 13 indicates that interpersonal relationship with workers under self and co-workers does not show any considerable impact on level of work-motivation of the workers. Whereas considering interpersonal relationship with senior officials, Table 13 clearly shows that where relationship are very good, level of motivation is high and, where interpersonal relationship are not good, level of motivation is low.

Table 13

Interpersonal Relationship \& Level of Motivation

\begin{tabular}{|c|c|c|c|c|}
\hline Sr. No. & Interpersonal relationship & & notivation & Total \\
\hline & & High & Low & \\
\hline \multirow{5}{*}{1} & Workers under self & & & \\
\hline & Very good & $51(46.79)$ & $58(53.21)$ & $109(100)$ \\
\hline & Moderate & $09(7.57)$ & $110(92.43)$ & $119(100)$ \\
\hline & Not good & -- & $22(100)$ & $22(100)$ \\
\hline & Total & 60 & 190 & 250 \\
\hline \multirow{5}{*}{2} & Co-Workers & & & \\
\hline & Very good & $57(61.96)$ & $35(38.04)$ & $92(100)$ \\
\hline & Moderate & $03(2.05)$ & $143(97.95)$ & $146(100)$ \\
\hline & Not good & -- & $12(100)$ & $12(100)$ \\
\hline & Total & 60 & 190 & 250 \\
\hline \multirow{5}{*}{3} & Senior Officials & & & \\
\hline & Very good & $54(83.07)$ & $11(16.93)$ & $65(100)$ \\
\hline & Moderate & $06(5.12)$ & $111(94.88)$ & $117(100)$ \\
\hline & Not good & -- & $68(100)$ & $68(100)$ \\
\hline & Total & 60 & 190 & 250 \\
\hline
\end{tabular}

Table 14

Resemblance of Objectives \& Level of Motivation

\begin{tabular}{lllrr}
\hline Sr. No. & Resemblance of objectives & \multicolumn{1}{c}{ Level of motivation } & Total \\
\hline & & High & Low & \\
\hline 1 & Fully resembles & $56(72.73)$ & $21(27.27)$ & $77(100)$ \\
2 & Resembles to some extent & $04(2.88)$ & $135(97.12)$ & $139(100)$ \\
3 & Do not resembles & -- & $34(100)$ & $34(100)$ \\
& Total & 60 & 190 & 250 \\
\hline
\end{tabular}

Table 14 high-lights that 139 respondents are of the opinion that there is resemblance to some extent with objectives of organization. Among this, 135 (97.12\%) respondents have low level of work-motivation while only a small proportion $04(2.88 \%)$ respondents have high level of work-motivation.

This foregoing analysis clearly shows that there is always conflict between informal group goal, and organizations goal. Because of this reasons, the goals of the informal groups are not easily satisfied. So there is low level of work-motivation.

\section{Conclusions}

On the basis of given objectives, hypothesis and a brief summary the following conclusions (Major findings) are drawn. 
(1) Job satisfaction and commitment as indicators of motivation being a qualitative variable was to be measured without which it was highly possible for the researcher to reach the conclusion. Likert type attitude scale of job satisfaction and commitment formulated by "canes" model of work-motivation provided result of workers motivation level was very low and with the help of such measurement, other variables were tested by cross tabulation. Further analysis of the Likert type attitude scale of job satisfaction and commitment reflects that the workers cannot take decision in relation to their job and hence they feel alienated while performing their task. Further they have no authority to exercise power so they feel power-lessens. Because of this they cannot influence other people in relation to their performance and accordingly feel meaningless to work for the organization. As far as the value of the job is concerned, the overall faith on the part of the worker is at lower level and feel normlessness to perform their job. There is deviation between the workers objectives and managements objective. The workers would like to work at average level irrespective of their ability. Since there exist the deviation between the workers objective and management's objective, the workers in the organization are not committed to achieve the organizational goals. Most of the workers are not aware of the norms of the organization and the mental condition on the part of the workers is not perceived to be positive to achieve the organizational goals.

(2) The researcher had curiosity to test the hierarchy of needs among the workers in Western Coalfields Limited, Chandrapur Area, and it was found that the hierarchy of needs according to workers were 1st self actualization at work place. IInd safety and social security. IIIrd Esteem, IVth social recognition and lastly Vth physiological. This newly developed model differs from A. H. Maslows theory of need hierarchy. It is because self actualization at work place and safety, social security needs are not satisfied in the organization. Hence the workers have low level of motivation.

(3) It is already mentioned that the design of study was descriptive as well as diagnostic. As far as diagnosis is concerned, the researcher tried to find out impact of personal factors on the level of motivation. The conclusions in this matter were very much surprising because directly or indirectly reverse factors had impact on the level of motivation such as youngsters were not highly motivated than the middle aged workers. It is also seen that the less educated were more motivated as compared to highly educated workers. The length of service and high skill ability have shown low motivation toward the work. The cause of low motivation among highly salaried workers show that they had low level of motivation.

(4) Financial motivation, as thought by the researcher, is major motivating factor for any human being. Present organization has ample of monetary incentives and motivation plans but it was found that all the monetary variables tested under present study has shown that it has hardly any role in increasing the level of motivation. For example, wages, Bonus, Quarterly Bonus, production bonus, provident fund, gratuity have hardly any bearing on the increment of motivational level, similarly annual leave, leave, leave travel-concession, replacement job to handicapped, accident compensation cannot provide much motivation for devoted work due to the financial policy of the management as well as the lingering procedure of settlement. Actually such financial motivations must increase their motivational level, a general law, but the result is not like that.

(5) Non-Financial factors as considered by researcher can play a vital role in motivation when also taken into consideration in the present study. In the same way as it was thought by the researcher maintenance factors like working condition, welfare facilities, and interpersonal relations cannot be kept all of from the motivation. 
(6) Human relations are domain of all sort of human interactions. Mutual awareness and reciprocity keep human bonds much closer, hence inter personal relations was one of the factors related to level of motivation. The result shows that workers having relation with sub-ordinate and co-workers do had low level of motivation vice-versa good relations with seniors in high level of motivation but number of such workers was very low.

Reviewing all the conclusions, in short, it can be revealed that the workers in Western Coalfields Limited, Chandrapur Area, are never in high level of work motivation which may hamper the well being of the worker as well as the organization.

\section{Review of Hypothesis}

The following hypothesis were reviewed on the basis of systematic the study, findings and micro-analysis of motivational aspects of coal mines workers of Western Coalfields Limited, Chandrapur area.

(1) The level of motivation of workers (High-Low) is closely related with the fulfillment of their expectations from their job. This Hypothesis is proved from Table 1 and Table 2;

(2) The set of hierarchy of motives of worker changes according to the personal and family background This Hypothesis is proved from Table 3, Table 4, Table 5, Table 6, and Table 7;

(3) Informal groups within the Industry are more motivated by their informal norms rather than industrial motivators. This hypothesis is proved from Table 14 .

\section{Generalization}

On the basis of the above proved hypothesis, if they are generalized in the frame work of any social theory, the theoretical base will be as follows:

(1) Any formal organization which does not fulfill the job expectations, the employees will be less work-motivated.

(2) Maslow's hierarchy of needs theory is changing according to the changing society. People on job can satisfy their basic and personal needs, but their need of self actualization in a complex Bureaucratic organization are not fully satisfied hence in the light of such situation. It can be generalized that the model of hierarchy of needs in the progressive society changes as per the felt needs. In modern formal organization the need of self-actualization at work place is important for high motivation potential.

(3) The third proved hypothesis leads such generalization that the motivation depends upon the theory of "pleasure and pain" more the pleasure more work-motivation, less the pleasure less the work-motivation, and also more the pain less the work motivation and less the pain more the work motivation.

(4) In any formal organization mere financial motivators do not lead to high motivation, non-financial motivators play equally important role in raising the level of work-motivation.

(5) Homans theory of small group within the formal organization has been proved in this study hence it can be generalized that formal groups always lead to form informal groups with their values and normative patterns.

\section{Exploration of New Hypothesis}

After careful investigation, systematic study and micro analysis of the present study the researcher had some new hypothesis in his minds. This hypothesis are as follows:

(1) Younger workers are less motivated than older workers. 
(2) More educated workers have low level of motivation than less educated workers.

(3) The hierarchy of needs of workers changes according to their expectations from their job.

(4) The predicted utility of earning a non-monetary incentive increases with the social value of the award.

(5) Organization that use non-monetary incentives have more committed workers than organizations that use only cash incentives.

(6) Employees remember non-monetary awards longer than cash rewards.

(7) Positive memories of non-monetary awards leads to higher levels of organizational work motivation and higher levels of organizational citizenship behavior.

(8) There is always a conflict between informal group goals and organizational group goals.

The above hypothetical statements were made by the researcher after Completion of this present study.

\section{References}

Clifford, T. M. et al. (1999) . Introduction to psychology. New Delhi: Tata Mcgraw-Hill Publishing Company Limited. Flippo. (1993). In C. B. Mamoria. Personnel management. Bombay : Himalaya Publishing House.

Frank, S. F. (1962). Theory and practice of psychological testing. New Delhi: Oxford \& IBH Publishing Co-Pvt, Ltd. Fred, L. (1995). Organizational behavior (7th Ed.). New York: Mcgraw-Hill international Editions.

Hugo, F. R. (1976). Dictionary of social science. London: Routledge and Kegan Paul.

Maslow, A. H. In Paul Hersery et al. (1988). Management of organization behavior. New Delhi: Prentice Hall of India Private Ltd.

Mitchell, G. D. (1968). A dictionary of sociology. London: Routledge and Kegan Paul.

Rajendra, K. S. et al. (n. d.). Social psychology (pp. 192-193). New Delhi: Atlantic Publishers and Distributors.

Robert, A. B. et al. (1988). Social psychology, understanding human interaction. New Delhi: Prentice Hall of India Private Ltd.

Saul, W. G. In C. B. Mamoria. (1993). Personnel management. Bombay: Himalaya Publishing House.

Scott, W. et al. (1977). Personnel management principles practices and point of view. New Delhi: Tata McGraw Hill Book Company. 